\section{New Foreign Members of the Linnean Society}

AT the meeting of the Linnean Society of London on May 12, the following were elected foreign members :-Prof. Klas Robert Fries, director of the Botanic Garden, Stockholm, who has made very important contributions to our knowledge of the flora of South America, chiefly of the Argentine, Bolivia, and Brazil. His work on the tropical American Anonacece, Amarantacece, and Colamniferce (Malvales) and his monographs of Wissadula and Petunia are especially noteworthy. He has also done valuable work on the flora of Rhodesia, the Congo, etc., and has made contributions to mycology. Prof. Eduard Fischer, professor of botany at the University and director of the Botanical Institute, Bern, distinguished for his works on a wide range of mycological subjects since 1883. He has devoted especial attention to the Gasteromycetes, on which he contributed the section in Engler and Prantl's "Pflanzenfamilien". He has produced monographic studies of the Rusts of Switzerland, and carried out extensive studies of the biology of heterœcious rusts. He collaborated with E. Gaümann in the most complete work on the biology of parasitic fungi that has yet been published. Prof. Ludwig Jost, director of the Botanical Institute and Gardens, University of Heidelberg, known for his work as a teacher of plant physiology and his influence on the development of his subject. Prof. Émile Topsent, professor of zoology and comparative anatomy, University of Strasbourg, the leading authority in the world on sponges. His first paper was published in 1887, since when he has published a number of papers and several important books, including reports for the Prince of Monaco. His large quarto volume_-"Campagnes . . .", Monaco, 1928is the most up-to-date monograph on sponges.

\section{U.S. National Academy of Sciences}

IT is announced by Science Service that the follow. ing have been elected foreign associates of the U.S. National Academy of Sciences: Marchese Guglielmo Marconi; Prof. Karl von Goebel, Munich; Prof. H. Wieland, Munich ; Prof. Fritz Haber, Berlin. Fifteen new members were elected: Dr. R. T. Birge, University of California, physics ; Dr. E. G. Boring, Harvard University, psychology ; Dr. S. R. Detwiler, Columbia University, anatomy; Dr. W. A. Jacobs, Rockefeller Institute for Medical Research, New York City, chemotherapy ; Dr. D. W. Johnson, Columbia University, geology; Dr. L. O. Kunkel, Boyce Thompson Institute, Yonkers, N.Y., plant physiology ; Dr. K. Landsteiner, Rockefeller Institute for Medical Research, New York City, immunology and pathology ; Dr. W. C. Mendenhall, U.S. Geological Survey, geology; Dr. Marston Morse, Harvard University, mathematics; Dr. F. K. Richtmyer, Cornell University, physics; Dr. J. C. Slater, Massachusetts Institute of Technology, Cambridge, Mass., physies; J. R. Swanton, Bureau of American Ethnology, Washington, D.C., anthropology ; Dr. R. J. Trumpler, Lick Observatory, Mt. Hamilton, Calif., astronomy; Dr. E. W. Washburn, U.S. Bureau of Standards, and editor-in-chief of International Critical Tables, chem- istry ; Dr. J. B. Whitehead, the Johns Hopkins University, mathematics and philosophy.

\section{Jericho}

ReCent correspondence in the daily Press on the Exodus and its relation to the fall of Jericho was no doubt to some extent responsible for the interest taken in the account of the third season's excavations on the site of that city given by Prof. John Garstang before the Royal Asiatic Society on May 12. Although two seasons' work had produced no certain evidence of dating, Prof. Garstang on opening his third season had arrived at an opinion, based on the evidence of stratification as well as the absence of any sign of Mycenæan contact, that the conflagration which destroyed the city, and of which there is abundant evidence, had taken place during the late Bronze Age, probably somewhere about 1400 B.c. With the view of obtaining datable objects which might or might not confirm this view, the Bronze Age cemetery some four hundred yards west of the city mound was attacked and twenty-five tombs were opened and cleared. Objects numbering eighteen hundred, the great majority pottery, were obtained covering the history of the site throughout the Bronze Age. Most significant of all, however, were ninety-four royal Egyptian scarabs, which have been examined by Prof. Newberry and pronounced by him to range from the Hyksos period to the reign of Amnhotep III. Egyptian influence first appears about 1500 B.C. ; but nothing of the Tel el-Amarna period and the age of Akhenaton has been found. It is, therefore, concluded that the city was destroyed at some date between 1411 B.c. and 1375 B.c. Evidence of reoccupation appears in the Iron Age; but the walls were not rebuilt until about 900 в.c.

\section{Excavation in Southern Palestine}

Sir Flinders Petrie briefly summarises the results obtained by the British School of Archæology in Egypt at Tel Ajjul up to the close of the past season's excavations, in the Times of May 13. The results fully bear out his opinion that the early history of Palestine has been more fully explained on this site than on any other in the country. The evidence it has afforded extends from the rockcut tombs of the Copper Age, c. 3400 B.c., in which copper daggers and pottery were found, to the age of Thothmes III., after whose day the site was abandoned until it was occupied again by Arab squatters in the Middle Ages. No less than five palaces were erected on the limestone hill, of which the limits were artificially extended to take the greater area covered by the later buildings. The first palace was erected by the people who introduced bronze from North Syria and whose invasion founded the Eighth Dynasty of Egypt. The second palace, Sir Flinders considers, was probably erected by the founders of the Twelfth Egyptian dynasty, while the third and fourth were the work of the Hyksos. The later Hyksos palace has afforded evidence of a foundation sacrifice in which the body of a horse was flung into a pit. Its shoulders and the bodies of two other horses afforded the 